\title{
Innovation Labs in the Public Sector: what they are and what they do?
}

\section{Introduction}

Innovation labs (i-labs) are becoming increasingly popular in the public sector. In 2013, Parsons DESIS lab (the New School for Design) published the 'Government Innovation Labs Constellation 1.0' covering 16 of such innovation outfits. Subsequently Nesta and Bloomberg Philanthropies have published a report on public sector innovation labs that covered 20 such units around the world (Puttick et al. 2014). ${ }^{1}$ While these reports have been informative in nature, there is very little research on public sector i-labs beyond descriptive - and at times normative - overviews. Mostly i-labs are described as versions of existing organisations: as hybrids of think tanks, digital R\&D labs, social enterprises and charitable organisations (e.g., Williamson 2014). The nature, organizational structure and need for such units within the public sector is largely unexamined.

With this article we will try to take a first systematic step to fill this gap in academic literature. In this paper we describe the foci and parameters of innovation labs to explain the existence of such organizations within the public sector. As i-labs deal with change, we will first look at how organisation theories have conceptualized change in the public sector and especially, why these new forms of organisations are created. The article argues that any singular organisation theory alone is not able to explain the emergence

\footnotetext{
${ }^{1}$ In the current research, i-labs were defined as organizations created to deal with public sector innovation partially or entirely financed by the public sector. Organizations primarily concentrating on broader engagement (social innovation) or created by international organizations (e.g., UN) were left out of the study. Our sample of i-labs is primarily based on the two aforementioned reports (Parsons DESIS lab/Nesta and Bloomberg Philanthropies) and our own additional research. Thus, the sample is based essentially on self-identification and visibility. Clearly, however, the number of such organizations is globally constantly increasing.
} 
of i-labs and thus, their existence can add considerable value to the theoretical debate. Emergence of innovation labs can be seen as one of the elements in on-going public sector innovation discourse and related reform attempts. Public sector innovation as a phenomenon is much less understood and discussed than its private sector counterpart (Pollitt 2011; Lynn 2013; Kattel et al. 2014), nevertheless one can witness across the world an emerging public sector reform trajectory where governments try to re-organize their innovation processes that are driven by technological change (ICT) and user- and citizen-centric governance and management ideas. In the context of i-labs what is relevant is that such organizations see innovation in public sector - however defined and understood - as their main task and indeed their raison d'être. I-labs are a specific activity by public sector to create organizations for innovations. In effect, studying ilabs - why do such organizations emerge - is one way to try to understand better what innovation in public sector is and how it takes place.

The theoretical discussion is followed by an empirical account of 11 i-labs across the world to illustrate how and why i-labs are created, what role they play and how they have persisted in the public sector. An integrative data analysis method is adopted for the empirical analysis triangulating data from in-depth interviews, document analysis and survey of i-labs. The article ends with a discussion about what i-labs tell us about change in the public sector and how previous theoretical approaches could be complemented.

\section{Theoretical overview: origins of organizational change}


The theoretical and conceptual explanations on public sector change are plenty, yet they tend to be loosely linked (Pollitt 2009). There are many organisation theories that explain the origin of organisations from modern organisation theories to evolutionary approaches. We know that organisations change and this change can be rather drastic e.g. from scientific management (Taylor 1911) to the rise of the network organisations (Baker 1992). Reviewing prior organisational theories - various strands of modern organisational, institutional, teleological, life-cycle, dialectic and evolutionary approaches - different core assumptions can be drawn (Table 1). However, the lack of explanatory power of these theories regarding the emergence of new organisational forms becomes evident. Thus, most of these theories do not outline how change is introduced to the system or environment. For example, most modern organisation theories assume that environmental changes cause organisations to adapt, while more institutional approaches, as mentioned above, rely on the idea of emulation as part of the diffusion process of new organisational forms (never really explaining the real impetus for change to begin with). More teleological organisational approaches are in essence introspective and assume that the change in organisations originates from within - through learning, especially during the search for more efficient forms of management and work organisation - and represent a utility-centred perspective. Thus, according to the rational perspective (epitomized by, e.g., delegation, principal-agent and bureau-shaping theories) involved stakeholders focus on the utility of dedicated structures and the consolidation of expertise in the former (James and van Thiel 2011; Pollitt 2004). While different in their assumptions, both strands assume that during the process of change some flexibility in organisational structures must exist to accommodate external complexity or internal learning. Somewhat differently, population ecology, organisation development theory and also evolutionary approaches 
assert that these new forms of organisation have to be protected from the traditional environment. $^{2}$ Evolutionary organisation theories put an additional focus on competition between the best organisational structures and highlight the importance of technology. While not evolutionary per se, both Weber's (2009) charismatic organization and Mintzberg's (1979) adhocracy can be seen as part of the former approach.

Table 1. Selection of organisation theories explaining organisational change*

${ }^{2}$ Organisation development theory goes a step further and asserts that these flexible structures are only temporal. 


\begin{tabular}{|c|c|c|c|}
\hline Theory & Main contribution & Hypotheses & Limitations \\
\hline \multicolumn{4}{|c|}{ Strands of modern organisation theory } \\
\hline $\begin{array}{l}\text { Systems theory } \\
\text { (Boulding 1956; } \\
\text { Katz and Kahn }\end{array}$ & $\begin{array}{l}\text { Organisations are (open) systems influencing and } \\
\text { been influenced by the environment they are in } \\
\text { Focuses on organisational structures, relationships, } \\
\text { and interdependence between elements } \\
\text { Elements of social systems are autopoietic }\end{array}$ & $\begin{array}{l}\text { Internal complexity is created to deal with } \\
\text { external complexity } \\
\text { Fluctuations from the } \\
\text { environment are adjusted to by organization } \\
\text { change }\end{array}$ & $\begin{array}{l}\text { Does not specify the reason behind the } \\
\text { need for collaboration that leads to change } \\
\text { Boundaries of systems are difficult to draw } \\
\text { Overestimation of management's role in } \\
\text { controlling systems }\end{array}$ \\
\hline $\begin{array}{l}\text { Contingency } \\
\text { theory } \\
\text { (Lawrence and } \\
\text { Lorsch 1967; } \\
\text { Burns and Stalker }\end{array}$ & $\begin{array}{l}\text { Different organisational structure are suitable for } \\
\text { specific environmental conditions } \\
\text { Variation in organisational structures is exp lained } \\
\text { by situational differences or contingency factors } \\
\text { (e.g. size, strategy, environment and technology) } \\
\text { Organisations adapt their structures to maintain a } \\
\text { fit and performance with the above factors }\end{array}$ & $\begin{array}{l}\text { During environmental change organic } \\
\text { organisational structures are most appropriate } \\
\text { Boundary scanning functions in organisations are } \\
\text { needed to respond to environmental demands } \\
\text { Managerial functions (incl. conflict resolution) } \\
\text { need to be differentiated to monitor change in } \\
\text { differing aspects of the environment }\end{array}$ & $\begin{array}{l}\text { Theory does not exp lain complex } \\
\text { relationships between organisations and } \\
\text { contingency factors (i.e. organisations are } \\
\text { assumed to have no significant influence } \\
\text { It is difficult to relate structure to } \\
\text { performance }\end{array}$ \\
\hline \begin{tabular}{|l|} 
Socio-technical \\
theory (Mayo \\
1946; Trist 1978)
\end{tabular} & $\begin{array}{l}\text { Experts as agents of change who design more } \\
\text { efficient work and workp laces considering human, } \\
\text { social and organisational factors }\end{array}$ & $\begin{array}{l}\text { For the adoption of new solutions both social } \\
\text { and technical factors need to be taken into } \\
\text { Legitimacy of experts as the driving force behind } \\
\text { organisational change }\end{array}$ & $\begin{array}{l}\text { Change usually addresses only work design, } \\
\text { not the processes of change itself } \\
\text { Socio-technical design methods are rarely } \\
\text { used in reality }\end{array}$ \\
\hline \multicolumn{4}{|c|}{ Institutional approaches } \\
\hline \begin{tabular}{|l|} 
New) \\
Institutional \\
(Powell and \\
DiMaggio 1991) \\
\end{tabular} & 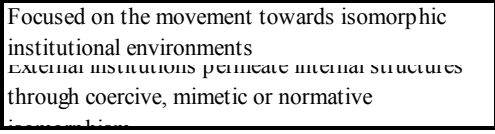 & $\begin{array}{l}\text { Organisational emulation leads to the adoption of } \\
\text { new structures }\end{array}$ & $\begin{array}{l}\text { Has typically a 'macro' focus } \\
\text { Does not concentrate on forces changing } \\
\text { institutional environments }\end{array}$ \\
\hline \multicolumn{4}{|c|}{ Teleological approaches } \\
\hline \begin{tabular}{|l|} 
Functionalist \\
organizational \\
theory (Child \\
1972; Donaldson \\
1987 )
\end{tabular} & $\begin{array}{l}\text { Purposiveness of the actor or unit as the motor for } \\
\text { organisational change - human intention as the } \\
\text { origin of new organisations } \\
\text { The functional consequence (feedback from desired } \\
\text { organisational performance) helps the structure to } \\
\text { persist }\end{array}$ & $\begin{array}{l}\text { When desired outcomes are not achieved through } \\
\text { existing organisational structures, it triggers the } \\
\text { formation of new organisations }\end{array}$ & $\begin{array}{l}\text { Highly positivist approach which does not } \\
\text { account for variety of organisational } \\
\text { structures and also complex (irrational) } \\
\text { change factors }\end{array}$ \\
\hline \begin{tabular}{|l|} 
Theory of \\
adaptive learning \\
(Cyert and March \\
1963, March \\
1981 and 1991) \\
\end{tabular} & $\begin{array}{l}\text { Organisations change as agents modify their } \\
\text { behaviour as a result of experience } \\
\text { Organisations are governed by dominant coalitions' } \\
\text { mental frameworks and organisational routines they } \\
\text { create }\end{array}$ & $\begin{array}{l}\text { The change of organisational structures is } \\
\text { dependent on how information in organisations is } \\
\text { acquired, interpreted and processed }\end{array}$ & $\begin{array}{l}\text { Excessively broad approach } \\
\text { Traditional approaches focus on the } \\
\text { individual level and less on organisational } \\
\text { learning systems }\end{array}$ \\
\hline \begin{tabular}{|l|} 
Theory of \\
generative \\
learning (Argyris \\
1977; Senge 1990)
\end{tabular} & $\begin{array}{l}\text { Organisations change through the individuals } \\
\text { learning activities and organizational learning } \\
\text { factors } \\
\text { In addition to adaptive learning processes (single- } \\
\text { loop-learning), organisations can also have } \\
\text { generative learning processes (double-loop- } \\
\text { learning): continuous experimentation and feedback }\end{array}$ & $\begin{array}{l}\text { Organisations usually cope with problems within } \\
\text { existing structures in single-loop-learning } \\
\text { processes; through double-loop-learning also the } \\
\text { broader organisation can change }\end{array}$ & $\begin{array}{l}\text { Concentrates traditionally on the individual } \\
\text { level (behavioural psychology); although } \\
\text { acknowledging the importance of change on } \\
\text { Does not exp licitly explain the emergence } \\
\text { of new organisational forms }\end{array}$ \\
\hline $\begin{array}{l}\text { Social construct } \\
\text { theory (Berger } \\
\text { and Luckmann } \\
1966 \text { ) }\end{array}$ & $\begin{array}{l}\text { Organisational change is based in human interaction } \\
\text { and described as a complex responsive processes } \\
\text { through common sense-making }\end{array}$ & $\begin{array}{l}\text { New organisational structures emerge through } \\
\text { interactions and changes in group knowledge and } \\
\text { subsequent praxis }\end{array}$ & $\begin{array}{l}\text { Discounts the effect of external factors; } \\
\text { especially downplay ing the effect of } \\
\text { technological determinism }\end{array}$ \\
\hline
\end{tabular}




\begin{tabular}{|c|c|c|c|}
\hline \multicolumn{4}{|c|}{ Dialectic/organisation behaviour approaches } \\
\hline $\begin{array}{l}\text { Conflict theory } \\
\text { (Collins 1974) }\end{array}$ & $\begin{array}{l}\text { Conflict as a form to socialise change is needed for } \\
\text { the formation and perseverance of social structures }\end{array}$ & $\begin{array}{l}\text { When there are conflicting approaches } \\
\text { challenging organisational structures need strong } \\
\text { promoters for effective conflict management }\end{array}$ & $\begin{array}{l}\text { Conflict theory does not explain } \\
\text { organisational stability }\end{array}$ \\
\hline $\begin{array}{l}\text { Agency theory } \\
\text { (Eisenhardt 1989) }\end{array}$ & $\begin{array}{l}\text { Division of principals and agents drives towards } \\
\text { specialization and autonomy }\end{array}$ & $\begin{array}{l}\text { Clearly delineated organisational structures and } \\
\text { roles reduce transaction costs and allow to create } \\
\text { the reputation of expertise. Insulating agencies } \\
\text { from third-party influence also advances their } \\
\text { fiduciary logic: politicians are able to show } \\
\text { credible commitment to the issue, thus, } \\
\text { diminishing political transaction costs }\end{array}$ & $\begin{array}{l}\text { Does not account for the effect of external } \\
\text { factors incl. technological change in } \\
\text { organisational change }\end{array}$ \\
\hline \multicolumn{4}{|c|}{ Life cycle approaches } \\
\hline \begin{tabular}{|l} 
Organisational \\
development \\
theory (Lewin \\
1947; Schein \\
1996) \\
\end{tabular} & $\begin{array}{l}\text { Change is imminent to organisations as external } \\
\text { environments transform } \\
\text { The 'unfreeze-change-refreeze model' }\end{array}$ & $\begin{array}{l}\text { Flexible organisational structures only exist } \\
\text { temporally }\end{array}$ & $\begin{array}{l}\text { Focuses on group formation and not } \\
\text { organisational change } \\
\text { Assumes a linear process of change } \\
\text { Non-temporal nature of change not } \\
\text { accounted for (possibility of no refreeze) }\end{array}$ \\
\hline \multicolumn{4}{|c|}{ Evolutionary approaches } \\
\hline $\begin{array}{l}\text { Population } \\
\text { ecology (Hannan } \\
\text { and Freeman } \\
1989 \text { ) }\end{array}$ & $\begin{array}{l}\text { Darwinian approach which argues that resource } \\
\text { constrained competition determines the survival of } \\
\text { superior organisational structures } \\
\text { Selection of various organisational structures is a } \\
\text { purposeful managerial choice }\end{array}$ & $\begin{array}{l}\text { Experimentation is institutionalized to achieve } \\
\text { variation in organisational structures } \\
\text { New organisational structures are retained via } \\
\text { standardization and institutionalised controls }\end{array}$ & $\begin{array}{l}\text { Organisations power to influence the } \\
\text { environment is ignored }\end{array}$ \\
\hline $\begin{array}{l}\text { Punctuated } \\
\text { equilibrium } \\
\text { theory (Tushman } \\
\text { and Romanelli } \\
1985)\end{array}$ & $\begin{array}{l}\text { Change occurs when the system has evolved } \\
\text { further from equilibrium } \\
\text { Organisational evolution is not an exponential } \\
\text { growth model, but caused by exogenous factor(s) in } \\
\text { the organizational environment } \\
\text { Organisational life is usually stable }\end{array}$ & $\begin{array}{l}\text { Clear stimulus of an environmental change is } \\
\text { needed for organisational change } \\
\text { New organisational structures evolve in smaller, } \\
\text { protected populations }\end{array}$ & $\begin{array}{l}\text { Discounts the importance of incremental } \\
\text { changes } \\
\text { Loses sight of some contextual factors } \\
\text { (including geography) }\end{array}$ \\
\hline $\begin{array}{l}\text { Theory of } \\
\text { disruptive } \\
\text { innovation } \\
\text { (Christensen } \\
\text { 1997) }\end{array}$ & $\begin{array}{l}\text { Disruptive technological innovations create new } \\
\text { functionalities, markets etc. } \\
\text { Traditional organisations have difficulties adapting } \\
\text { to changes due to client bases and established } \\
\text { routines }\end{array}$ & $\begin{array}{l}\text { Technological change explains the need for } \\
\text { flexible organisational structures }\end{array}$ & $\begin{array}{l}\text { Concentrates specifically on the private } \\
\text { sector competitive market context } \\
\text { Too broad application of 'disruptive' } \\
\text { change - dissolution of the concept }\end{array}$ \\
\hline $\begin{array}{l}\text { Theory of techno- } \\
\text { economic } \\
\text { paradigms } \\
\text { (Perez 1983; } \\
\text { Freeman and } \\
\text { Perez 1988). }\end{array}$ & $\begin{array}{l}\text { Organisational evolution is explained by a } \\
\text { mismatch between socio-institutional and techno- } \\
\text { economic paradigm }\end{array}$ & $\begin{array}{l}\text { Organisational structures adapt to the logic of the } \\
\text { techno-economic paradigm } \\
\text { Fluid, exp erimental periods proceed new } \\
\text { emergence of dominant paradigms }\end{array}$ & $\begin{array}{l}\text { Assumes a high level of technological } \\
\text { determinism }\end{array}$ \\
\hline
\end{tabular}

Source: Authors.

*Some ideal types of organisational models from Van de Ven and Poole (1995) were used in the overview to categorize organisational theories.

Nevertheless, most organisation theories are developed in the private sector context, assuming, in effect, an environment of market economy and high levels of competition.

Taking into account the contextual characteristics of public sector organizations, we can discern six reasons from classical organisational and evolutionary theories why ilabs could be created: external complexity (environment), technology, competition between old and new structures, emulation, consolidation of expertise and learning (Figure 1). And, by a proxy, we can argue that these six reasons for organizational change help to explain also public sector innovation and related reform patterns. 
Figure 1. Schematic representation of theoretical expectations behind the creation of i- labs*

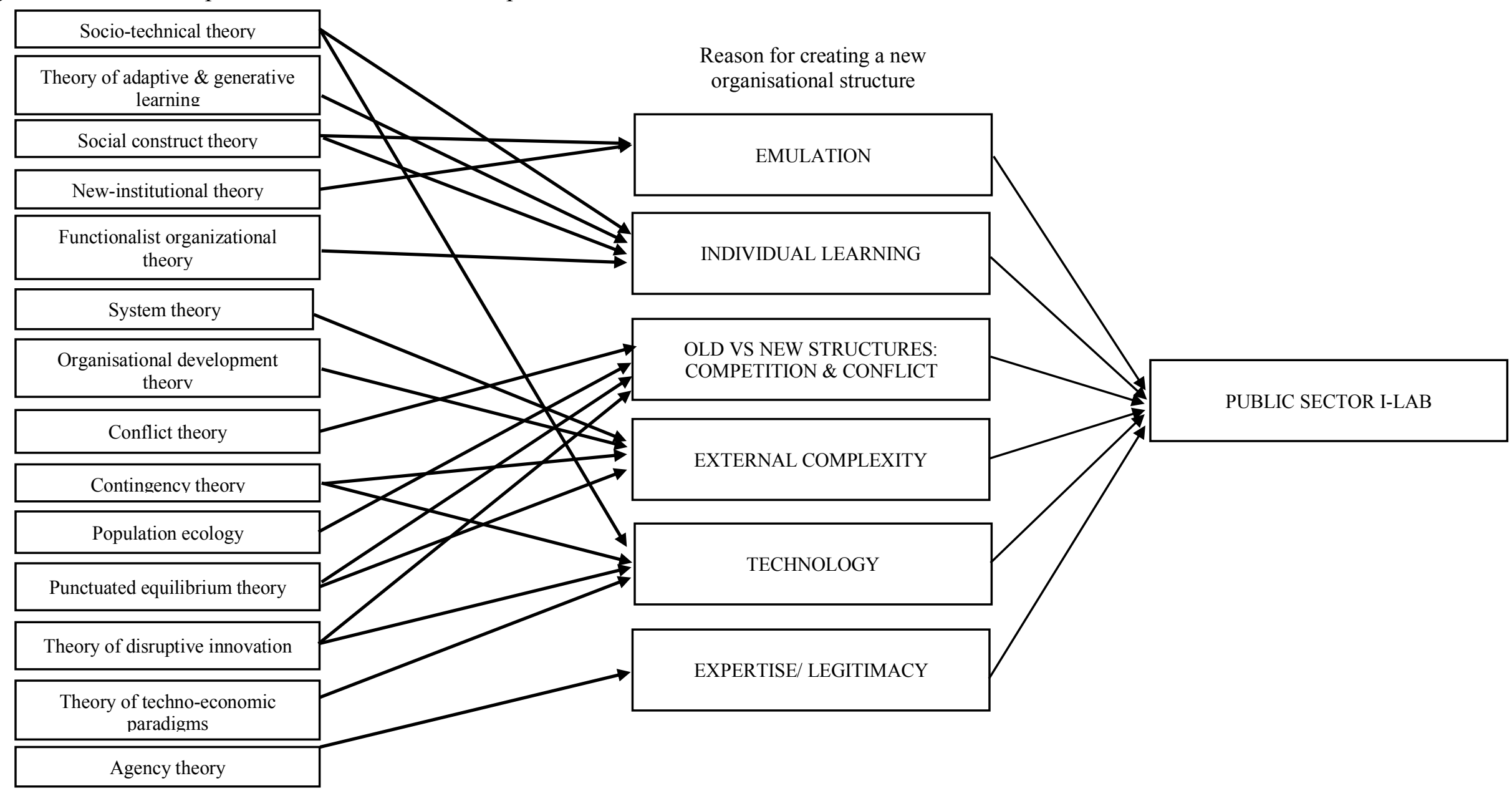

Source: Authors. 
Figure 1 shows schematically that the explanatory factors derived from different theories do not systematically follow boundaries of traditional (ideal type) division of organisational theories (didactic, evolutionary, teleological etc.). The emergence of new organisational forms that could explain the existence and role of i-labs is a sidetopic in traditional organisational theories and thus, the assumptions fluctuate between and within different theoretical approaches. Table 2 pulls together the main theoretical propositions from the material presented in Table 1 and Figure 1.

Table 2. Propositions

\begin{tabular}{|c|c|}
\hline Prepositions & Theories \\
\hline $\begin{array}{l}\text { Preposition 1. I-labs are created in the public sector } \\
\text { to cope with external complexity (e.g. the rise in user- } \\
\text { led exp ectations; austerity). }\end{array}$ & $\begin{array}{l}\text { Systems theory, contingency theory (modern organisational theories ), } \\
\text { organisation development theory (life-cycle), and all evolutionary } \\
\text { approaches }\end{array}$ \\
\hline $\begin{array}{l}\text { Preposition 1.1. I-labs are specifically created to } \\
\text { cope with technology-induced (ICT) demands on the } \\
\text { public sector. }\end{array}$ & $\begin{array}{l}\text { Contingency theory (modern organisational theories); theories of } \\
\text { disruptive innovation and techno-economic paradigms (evolutionary) }\end{array}$ \\
\hline $\begin{array}{l}\text { Preposition 2. I-labs are created in the public sector } \\
\text { to cope with internal learning (e.g. search for } \\
\text { productivity gains). }\end{array}$ & $\begin{array}{l}\text { Teleological approaches : functionalist organizational theory, theory of } \\
\text { adaptive and generative learning, social construct theory; and also socio } \\
\text { technical theory (modern organisational theories ) }\end{array}$ \\
\hline $\begin{array}{l}\text { Preposition 3. I-labs are created in the public sector } \\
\text { to shield new, change-oriented structures from } \\
\text { internal competition within tradition organisation } \\
\text { structures. }\end{array}$ & $\begin{array}{l}\text { Conflict theory (dialectic) and evolutionary approaches : population } \\
\text { ecology, punctuated equilibrium theory, theory of disruptive innovation } \\
\text { theory }\end{array}$ \\
\hline $\begin{array}{l}\text { Preposition 3.1. I-labs are created in the public } \\
\text { sector to legitimise change through specialisation and } \\
\text { the concentration of experts. }\end{array}$ & Agency theory (dialectic/organisation behaviour) \\
\hline $\begin{array}{l}\text { Preposition 4. I-labs are created in the public sector } \\
\text { due to (private sector) emulation and information } \\
\text { exchange. }\end{array}$ & Institutional approaches plus social construct theory (teleol \\
\hline
\end{tabular}

Source: Authors.

Contextual factors (propositions 1), such as the economic crisis and the resulting fiscal austerity, seem to pressure public sector organisations to search for more efficient public service delivery mechanisms. For example, new public governance and public sector innovation literatures emphasize the need to incorporate service technology principles into public management and administration (Osborne and Brown 2013). Here collaboration with outside stakeholders is seen as key (Pärna and Tunzelmann 
2007; Kim 2010). Hence, the existing literature on i-labs seems to suggest that the surge of innovation labs also in the public sector can be tied to (lead) user-centred approaches (e.g. co-creation, co-design and co-production) (Bason 2013; Mulgan 2014) - meant to cope with external complexity - powered by the popularity of 'open' innovation models during the previous decade (Chesbrough 2003).

As mentioned above, under evolutionary approaches the theory of disruptive innovation and techno-economic paradigms tie organisational change directly to radical change in technology. This in broad terms is also an environmental contingency, but the theories assume that radical change in technology causes a cumulative change in the sociotechnical system (proposition 1.1.). While this might be critiqued for being overly deterministic, it has garnered a wide response from management scientists, who see it as a central factor on how private sector organizations change (e.g., Rogers 1995; Tushman and O'Reilly 2002; Christensen and Raynor 2003; Christensen 2006); yet, these assumptions have been underutilised in public administration literature (Pollitt 2010; Margetts and Dunleavy 2013). Thus, we cannot ignore the role of information and communication technology (ICT) as an independent variable in the process. With the specifics of the technology and more access to data, public services are becoming more modular and open to outsourcing and decreasing the need for middle management (e.g., Langlois 2007) and thus, open to incremental, intra-service changes without the direct need to re-arrange the service system. Nevertheless, these learning effects do not have to be only exogenously motivated (i.e. due to technology, austerity), but they can also be caused by internal processes - e.g., search for efficiency gains - which may also be reason to create i-labs (proposition 2). 
On the whole, existing literature proposes that i-labs are foremost created to foster ICTenabled user-driven service production logic in the public sector as well as to cope with external changes (ICT change, austerity, demand for individualized services). It is assumed that i-labs represent islands of experimentation where public sector can test and scale out public service innovations. In the same vein, we can use March's classic dichotomy of explore and exploit here: i-labs could be described as organizations established to explore new opportunities (i.e., innovations) in existing services or creating entirely new ones (see March 1991 on explore and exploit). It follows logically that experimentation assumes some level of autonomy from the existing structures and institutions (Coriat and Weinstein 2002), and one can understand i-labs as an attempt to create independent change champions (experimental organizations) within the public sector (proposition 3). For this some form of legitimacy (from expert knowledge, specialization) is needed (proposition 3.1.). Moreover, in many ways the approach to create new organizations within the public sector rather than reforming the existing ones or calling on private organizations represents an attempt to mimic the market context, where innovations spread through new types of organizational routines replacing the old ones (proposition 4). 


\section{Methodology}

Innovation labs, both in the private and public sector, are very heterogeneous - in terms of their activities, scale and organizational structures - making them difficult to map and analyse. An integrative data analysis method is adopted for the empirical analysis triangulating data from in-depth interviews, document analysis and survey of i-labs. In the two-step approach, first, a comprehensive survey was carried out directed at the management of innovation labs, followed by an extensive in-depth interview with the same managing figures of i-lab. The survey is based on long-term and large scale research into public sector organizations in Europe - COBRA research project. Based on proven structure and logic, the COBRA questionnaire addresses the autonomy of agencies towards their political and administrative principals on different dimensions. ${ }^{3}$ This is useful starting position for studying i-labs as they represent experimental organizations that almost by definition assumes autonomy from existing institutions (Coriat and Weistein 2002). However, due to the specific nature of i-labs, the questionnaire had to be significantly updated to fit our purposes of the research. ${ }^{4}$ The survey was followed by an in-depth, semi-structured interview (both with deductive and inductive questions) reflecting on the results of the survey and specifically focusing on the reasons behind the creation of the lab, team characteristics, main tools, network partners, activities and goals, outcomes and steering and control. The interviews were recorded, transcribed and additional notes from the authors were used to analyse the data. The research design was tested prior to use with the representative from Mindlab,

\footnotetext{
${ }^{3}$ The study covers more than 50 multiple choice and open-ended questions on organisational functions, income sources, legal basis, network, interaction with department/ministries, tasks, customers, competitors, characteristics of the organisation, autonomy, evaluation etc. More details can be found at http://soc.kuleuven.be/io/cost/survey/ (accessed 30.07.2014)

${ }^{4}$ We are grateful to Koen Verhoest from University of Antwerp for his help in updating the questionnaire.
} 
Denmark. $^{5}$ To encourage i-labs to be as frank as possible, their answers were anonymised and only direct references to individual labs will be made when the information was obtained from the desk research.

Based on prior reports by Nesta, IBM (Puttick et al. 2014; Burstein and Black 2014), Parsons "Gov Innovation Labs Constellation 1.0" and web-based searches we identified 35 i-labs in or directly funded by the public sector. ${ }^{6}$ Most of them could be found in Europe and North America, although, Asia is also showing growing number of such labs. In developing countries these labs (primarily social innovation labs) are usually found in the third sector and thus, outside of the scope of this research. Furthermore, ilabs established under the United Nations (including the UNDP Public Service Innovation Lab) were not considered for this research.

Prior to the survey and interviews, we made a profile for all i-labs in our sample based on document analysis. From the aforementioned 35 i-labs we were able to find direct contact information for 25 of the labs, from which 16 answered our initial interview request. In the end, 11 i-labs joined the full study of which 3 had closed down by the time of our in-depth study (see the list of interviews in the Appendix). ${ }^{7}$ Our study includes six i-labs from Europe, four from Northern America and one from Australia. The study does not aim for a representative sample of public sector innovation labs, as our goal was to reach the greatest possible amount of information on the phenomenon

\footnotetext{
${ }^{5}$ Mindlab is one of the most well-known public sector i-labs and is in many cases used as a blue print for future labs.

${ }^{6}$ The list and characteristics of individual i-labs is available on request. The information obtained from the survey is anonymised and available in a generalized format.

${ }^{7}$ The drop out was due to the extensive two-step study design, but only relying on the survey information was not feasible due the complementary topics under discussion during interviews.
} 
of i-labs and contribute to theory building (see Flyvbjerg 2006 on this methodological issue).

\section{Innovation labs in the public sector}

\section{General characteristics}

Innovation labs in our sample were established between 1999 and 2013, although, seven of the i-labs were established after 2010. From the total sample of i-labs (35) around one third were established under the municipal level, while others were created on the state or federal level. Approximately half of i-labs in our sample had their own legal personality separate from their parent organization (both vested in public and private law). At the same time, others were identified as independent parts of a ministry or municipal department (e.g. DesignGov, Laboratorio para la Ciudad) or did not exist in the formal organization at all, which was the case for one of the most well-known ilabs - Helsinki Design Lab - in SITRA.

I-labs in our sample of 11 employed from 2 to 17 people, with the average team size of 6-7 persons. While it was difficult for some i-labs to differentiate their own budget from the overall budget of the organization, the maximum budget in our sample was 1.5 million $€$ in the previous financial year. For over $60 \%$ of the teams the primary source of income was self-generated (for more than half of the labs this constituted more than half of their budget - see figure 2), although, closely followed by direct budgetary transfers from the government. In many cases, the internal funding (in addition to operating costs) came from specific projects or program partners within the public sector. This structure of finances was seen as important by i-lab executives: while the 
internal funding encourages ownership of projects inside the public sector, external funding gives the flexibility for i-labs to try new things: "We always leave some money to explore new possibilities, for skunk works."

Figure 2. Source of income provide more than half of the total budget $(\%$ of i-labs)

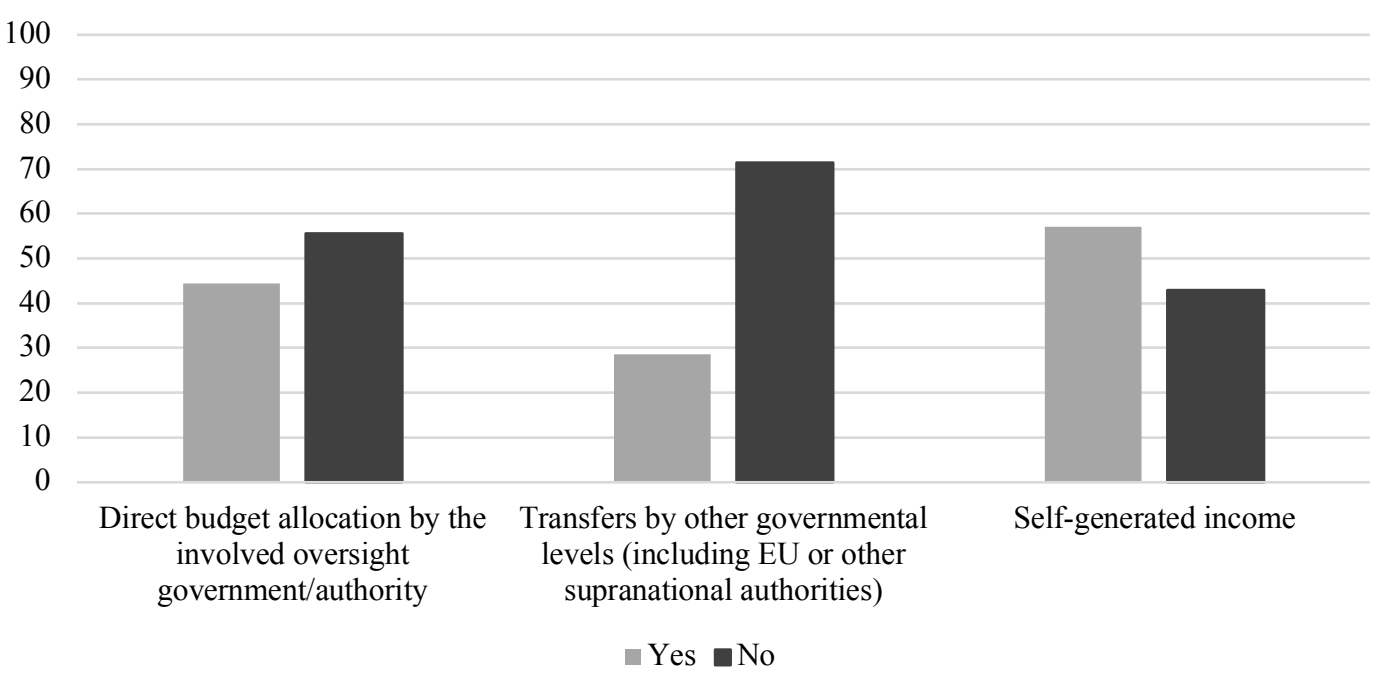

Source: Authors.

This gives also an indication of the power and control relations (autonomy) that separate these teams from the rest of the public sector: self-generated income and low operating budgets mean that most i-labs do not elicit strenuous performance evaluations nor the need to collect quantitative metrics to make the output of the labs measurable. Figure 3 and 4 show that traditional performance related measures and results-based planning are not used in the context of i-labs. 
Figure 3. Selected activities characteristic to i-labs: planning, evaluation and measurement $(\%)$

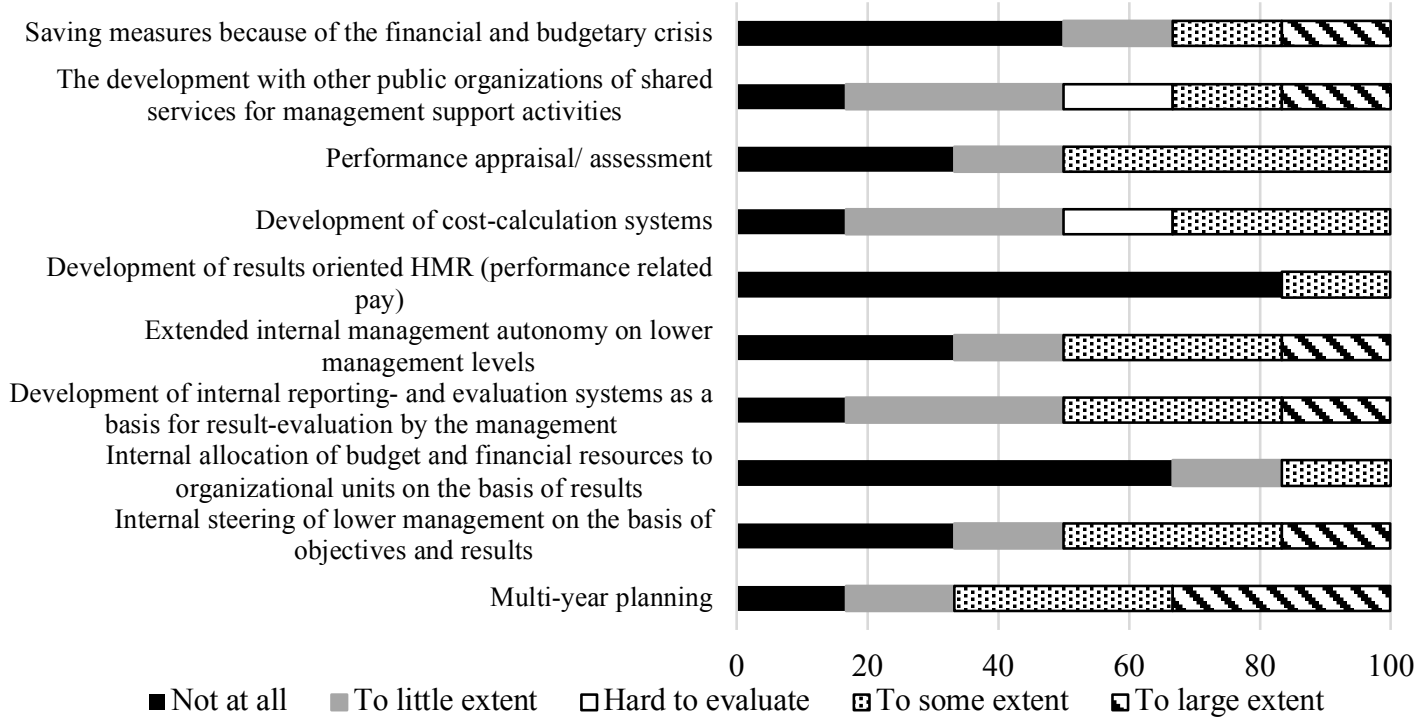

Source: Authors.

Figure 4. Traditional evaluation modes (\%)

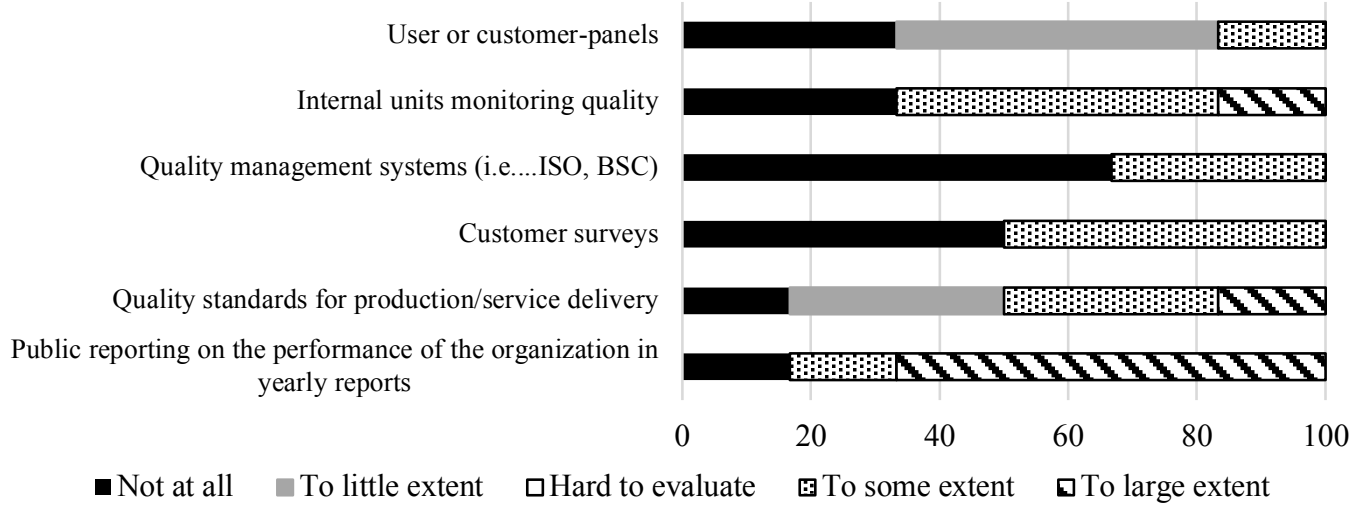

Source: Authors.

Usually formal indicators are used to communicate results monthly or quarterly between parent organization and i-labs, while more ethnographic methods (description of activities, video diaries, blogging, etc.) are used internally and to communicate results to the wider network of lab partners. The latter is more to legitimize lab activities in the eyes of the general public. Goal attainment is usually evaluated inside the organization itself and there are no direct performance rewards for results (apart from the possible increase in budget in few of the reviewed cases). While the impact of labs 
can be measured on different levels - the lab itself, the spin-offs it creates, innovations and innovators it supports and innovation discourse it helps to establish (Tiesinga and Berkhout 2014, 106) - soft outcomes (networks, discourse change etc.) - are by the account of i-labs themselves easier to achieve.

However, in terms of finances, outside control over i-labs is more rigorous: meaning that investment and annual budgets have to be coordinated with parent department or the financial department. Most are subject to external audit concentrating on financial issues and legality and rule-compliance. One third of i-labs found that the use of resources is evaluated to a very great extent and another third to some extent. Nevertheless, measurable targets are usually not tied to budget allocation and the former are set in most cases for internal use only. Used indicators usually describe activities and task performance, measuring quality of services and are both qualitative and quantitative in nature. However, when the budgets get higher and the activities become more visible, then calls for more precise control and 'meaningful' performance measures emerge (see in the case of the OPM lab in GAO (2014)).

This is also the reason why, as mentioned above, most executives saw the small size of i-labs as key to the success of their activities, otherwise the centre of control would go elsewhere and the steering of the i-lab would become more standardized, invariably influencing the core activities of the lab itself. This makes most i-labs small and agile: the lean, start-up type structure enables much quicker communication, forces labs to do things "quick and dirty", because there is not enough people nor budget to draw out the processes. When projects become too big, then invariably i-labs run against existing structures (e.g. IT departments and ICT architecture) and procurement rules. This was 
seen as cause for loss of momentum as "existing standards override everything". This indicates a strong disparity between old and new organisation structures in terms of doing things, while also limiting the effective autonomy of i-labs that is needed to challenge the old norms and institutionalize innovations on large scale.

Usually i-labs are built around a particular user-design led method such as humancentred design (MindLab), 'Friendly Hacker' method (La 27e Région) or four-step Innovation Delivery model (New Orleans Innovation Delivery Team) (see further Puttick et al. 2014). However when it comes to specific analysis techniques and skills, i-labs use a variety of approaches: randomized control trials, ethnography or action research to work directly together with the people impacted (see also Bellefontaine 2012; Puttick et al. 2014). Thus, i-labs usually bring together heterogeneous teams of researchers, designers, and stakeholders to discover and analyse problems from different angles and develop, test and improve prototypes for their practical application. Our interviews showed that i-labs employed both people from backgrounds generally new to the public sector - design, anthropology, ethnography, social geography - and people with more traditional skill-sets - political science, sociology, communication etc. What was striking was that while these labs are often associated with new ICT solutions and hackathons, there were not that many IT engineers present in the labs that where in our sample - these skills where acquired from outside partners. In some sense, this can be seen as an attempt to make technology subservient to social change rather than letting the technology be the catalyst of the latter (see also Townsend 2013 on this point). At the same time, the cause for the former was also the fact that during the period of austerity is was not allowed to hire outside of the public sector. 


\section{Reasons behind the creation of $i$-labs and their main activities}

In general, the interviewed executives argued that i-labs were created to enable crossdisciplinary and citizen-driven approaches. Thus, we found most support for the role of external complexity and technology for the creation of innovation labs (propositions 1 and 1.1). The conflict between old and new organisational structures - propositions 3 was not brought out as a specific reasons (and many organisations did not have full independence or organisational segregation anyway). In general, internal learning effects were deemed subservient to external changes (proposition 2). However, both specific know-how and autonomy of i-labs was deemed essential for the survival of the organisations (see discussion in the next section). Furthermore, the growing number of various practical guides to lab building (e.g., Doorley and Witthoft 2012; Ståhlbröst and Holst 2013; UNICEF 2012; Puttick 2014) indicated that indeed some emulation and fad of labs can be justified as a causal factor. This was also corroborated by our interviews, as the first i-labs (especially Mindlab in Denmark) caught wide media attention and thus, were considered for emulation (proposition 4). This also corresponded with the fiduciary logic of specialized agencies (proposition 3.1) - hence, in many cases in our sample politicians were able to show credible commitment to innovation through the creation of public sector i-labs.

While the aforementioned were the main reasons mentioned for the creation of i-labs in the public sector, it does not mean that these goals and logics were specifically followed later on. The activities of i-labs beyond their initial goals of creation where connected to their position and routines within the public sector. For example, while stakeholder engagement and coproduction with citizens was seen as key, i-labs produced most of their work for or with the ministerial departments and other 
government agencies facilitating mainly inter-public sector learning processes (see figure 5). This is dependent on the fact that public sector funds a large share of i-lab activities. Thus, our survey results showed that parent organization (ministry or municipal department) and general public influence the direction and strategy of i-labs in our sample the most, while industrial partners, corporations and private consultants, individuals the least. Depending on the level where the innovation lab was established - local or national - the department of civil service played the central role in the strategy of i-labs. Consequently, while internal learning was not the cause for the creation of ilabs in most cases (proposition 2), it in reality became an important factor in what the organisations later on dealt with.

Figure 5. Target groups of i-labs (i.e. relevant users of the activities, services and/or products of i-labs; $\%$ of i-labs)

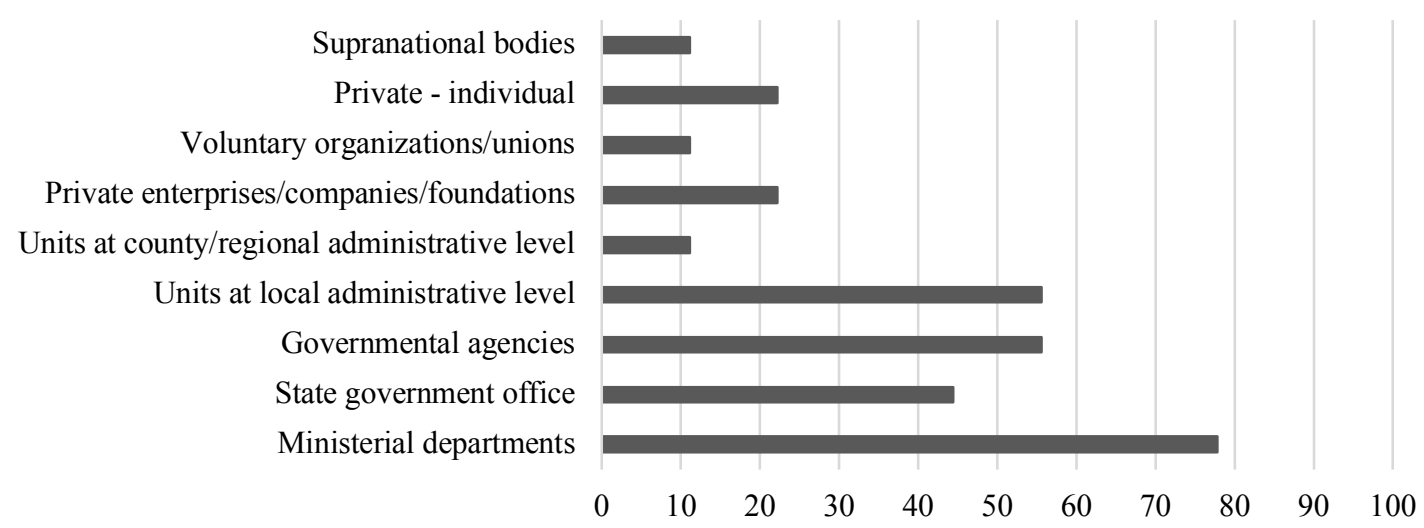

Source: Authors

As such, the level of collaboration among the target groups change in accordance with the orientation of i-labs as well (e.g. internal public sector processes). Burstein and Black (2014) differentiate between internally and externally focused innovation offices in the US city government context. While the first are foremost established to engage the public in crowdsourcing projects, community data collection and experimentation, then the internally focused offices are oriented towards increasing administrational 
efficiency (e.g. the work of most i-teams), produce an organizational culture change in larger organizations (employee innovation competitions and resident talent programs) and implement innovation processes and protocols inside organizations. The division of labs in our sample was almost half and half for both categories with the lead of citizen oriented, crowdsourcing initiatives. The level of collaboration is in both cases high due to the user-centred approaches that i-labs dominantly employ both in and outside of the public sector. Thus, collaboration - both inside and outside the public sector - and the ability to coordinate interdisciplinary user-needs across different partners is key for ilabs. Consequently, it is not surprising that the self-reported characteristics of i-labs are concentration of activities on building trust, individual/relational aspects, cooperation and empathy - see figure 6 . The most uncharacteristic feature the i-labs reported in the questionnaire was good financial rewards - again performance is not specifically evaluated - and the most neutral constructs were related to career development (figure 7).

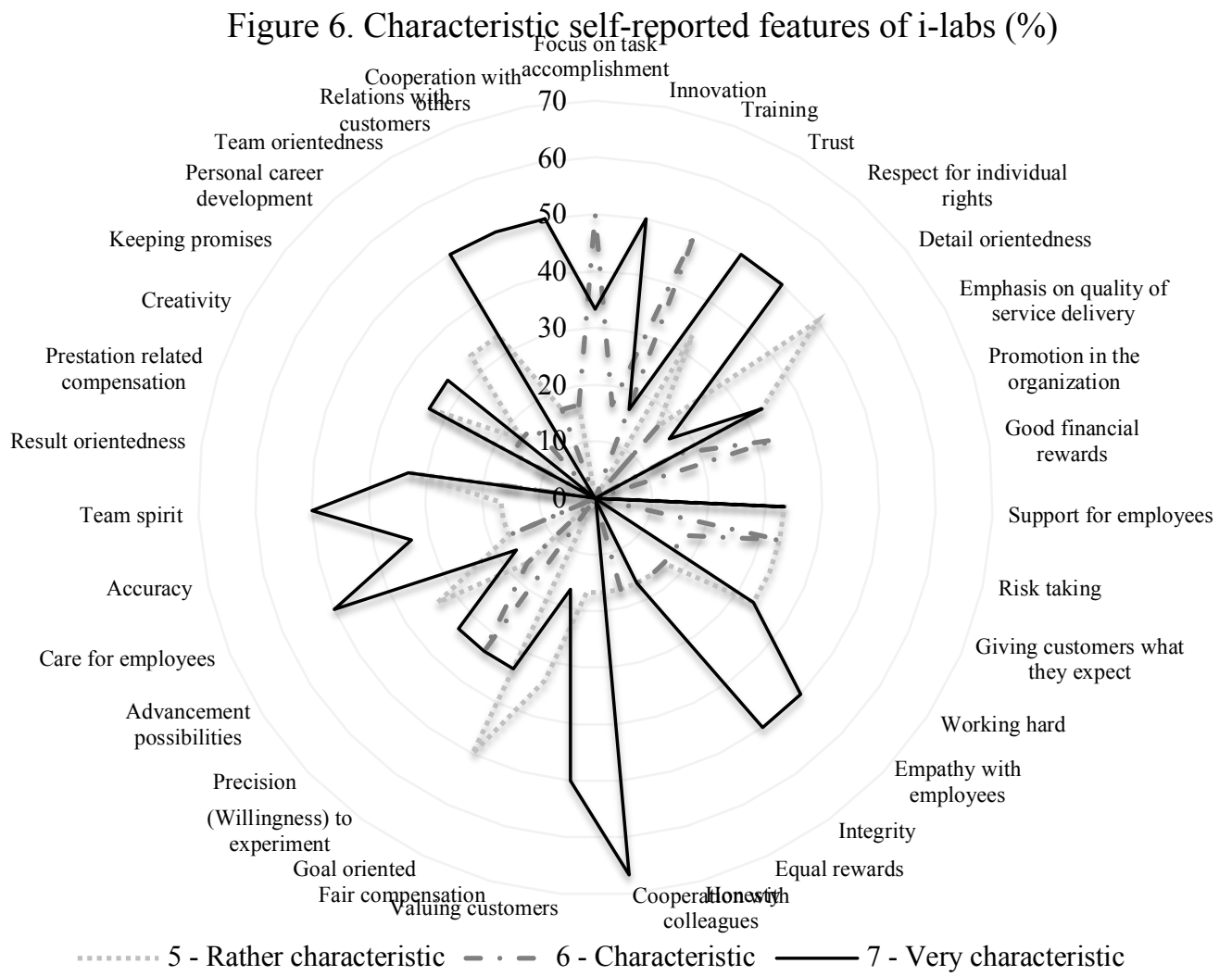


Figure 7. Most uncharaçteristic self-reported features of i-labs (\%)

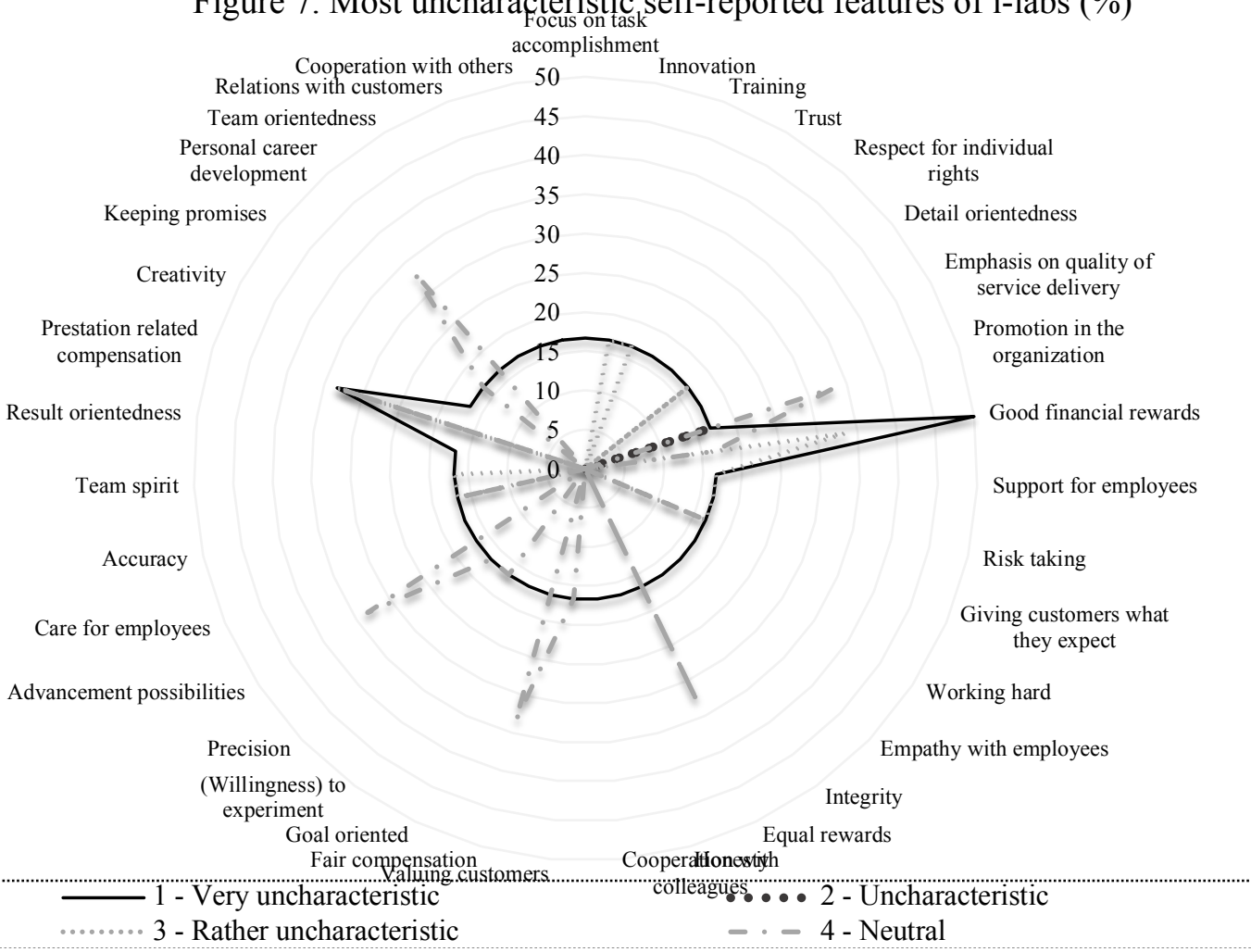

Over $60 \%$ of i-lab executives in our sample agreed with the need for the lab to coordinate with other government bodies on the national level, and $70 \%$ on the coordinate with local/regional government. Half of i-labs saw it as necessary to coordinate their activities with supra-national bodies and international organizations. At the same time, all i-labs agreed that they needed to coordinate their activities with private sector stakeholders, interest organizations, user groups and civil society organizations. Again, this can be considered as a limiting factor against effective autonomy to challenge unilaterally the existing routines of public sector. Figure 8 illustrates the most important partners for i-labs in our sample. 
Figure 8. Most relevant participants in networks outside of the organisation of origin ( $\%$ of $i-l a b s)$

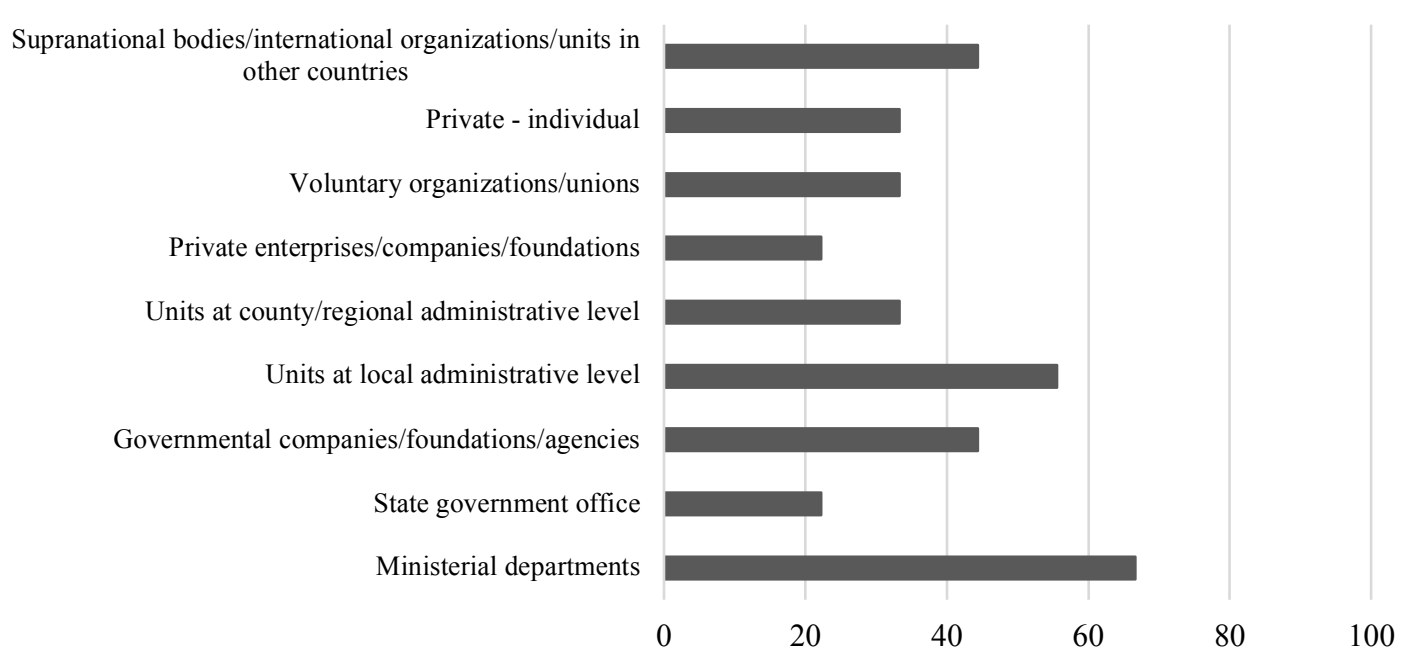

Source: Authors.

Most of the reviewed labs worked across government departments or agencies, some were established under different ministries (such as Mindlab). However, due to the nature of their activities and the methods they use, they are generally not understood in traditional (e.g. urban planning, engineering or IT) departments. I-lab managers acknowledged that organization culture was difficult for them to change (or even impossible under conditions of siloed public services and negative attitudes from public sector managers) and the solution to move forward was to target individual staff and get them to lead and take ownership of specific ideas, programs and practical solutions. This was called by one of the i-lab executives as the "Trojan horse strategy". Hence, informal networking (coffee tables etc.) and being present and seen in partner organizations was seen as very important ("when we are building a relationship, we never ask people to come to us - we always go to them"). While it was much easier for i-labs to include stakeholders from outside, they used personal relationships (both inand outside of the public sector) as leveraging tools to guarantee support to projects and the organization. 


\section{The dilemma of autonomy, control and survival}

One of the most important aspects of i-labs is the level of organizational autonomy which should allow the units to pursue discontinuous and disruptive innovations without the direct interference from the traditional organizational structures (proposition 2). The survey outlined that most i-labs in our sample were indeed characterized by high levels of autonomy with most units taking most of the decisions themselves with minister/parent department only slightly involved. Half of the surveyed i-labs considered their autonomy sufficient to a degree, others found it totally sufficient or hard to evaluate. When we look specifically at different factors of autonomy then we can see that two thirds of the labs had control over setting salaries and appointing and evaluating most of their staff. Furthermore, most organizations set their goals themselves with only third of i-labs having to consult their parent organization regarding the former. The same holds true for negotiations with external actors also from the international level.

Here it is important to outline sources of such high level autonomy. As exemplified by decades of discussion over principal-agent problems in the context of agencification, high level of autonomy is typically not readily accepted in the context of public sector. The in-depth interviews gave an idea of how this leeway is granted within the public sector context: the key source of the autonomy is the support of the high-level civil service executive or politician (minister, mayor etc.). Consequently, our survey showed a reportedly high level of support to the organization from the minister or head of the local administration. It seems that politicians indeed have a fiduciary relationship with the i-labs and they reap some rewards from public involvement and recognition of lab 
activities (in this regard lab activities can be associated with the newly defined conspicuous politics (Tõnurist et al. 2015)). In general, innovation labs both in public and private setting are supposed to hold the disruptive potential to the existing organization, so the existing routines, norms and organizational culture would not be able to immediately work against change. Thus, Bason (2013) descries these labs as 'authorizing environments' and some of these teams enjoy high media support (e.g. John 2014).

While public sector i-labs try to legitimize their activities to the general public by their active presence in media or through broad-based networks (e.g. through social media), the latter did not prevent the close-down of i-labs in the three cases in our sample (HDL, DesignGov, the Studio). The most significant factor of survival in these cases - and also identified by working labs - was chief executive support. When the former was lost (through the political process or change in leadership) then the debate surrounding the "hindrance or benefit" of these units started to emerge. Hence, the conflict between old and new structures is inherent. The core characteristics of the lab - smallness, (physical) separation, autonomy and also the lack of concrete performance measures start to work against the labs without the presence of an organizational sponsor: "we were not large enough to make it harder for us to close down; the rest of the organization didn't understand what we did; we weren't entwined with the system."

There are various reactions to this: some innovation labs saw their existence clearly as temporal (some interviewees cited their own results from their scoping works of similar i-labs highlighting that the average lifespan of such units was on average 3-4 years, basically "a lifetime of a high-level CEO") realizing that in the long term they would 
have to change too much to fulfil their initial task or more institutionalized forms of collaboration would not be of interest to the people involved (designers, architects, videographers), especially in the case when an outside lead to the lab was brought into the public sector to build up the i-lab (e.g. Laboratorio para la Ciudad). Some innovation units have started their existence with a sunset clause (e.g. the BIT unit in the UK), but managed to surpass the initial review due to rigorously documenting their output and developing metrics to substantiate it (which for most current i-labs would mean change (see e.g. in the case of Nesta in Puttick (2014)) and renew their political mandate; while some in different conditions have not (e.g. DesignGov in Australia)). Thus, for a longer term survival i-labs would probably need to change their organizations and engage the public sector in more broad-based activities (examples here could include Nesta in the UK; or even Mindlab in Denmark which has had different waves of activities). When it comes to small-scale 'labbers', they see i-labs more as a format of 'guerilla warfare' or 'guerilla army' of Pro-Ams (professionals-amateurs) to expand the political space (e.g. Leadbeater and Miller 2004, 59) and hence, temporality is not a problem.

However, what is surprising in the context of the aforementioned - autonomy created by high level political support and the antagonistic nature of their activities in terms of the prevailing organizational culture - is that i-labs in general do not (nor did they in our interviews) acknowledge the 'political' nature of their existence and rather emphasize the 'objective' or 'neutral' nature of their activities. This has been previously called the 'political blind spot' of i-labs (Kieboom 2014). Nevertheless, most lab activities were to some or great extent connected to policy development or making proposals thereof; however, when it came to political tasks (providing council to minister or mayor or helping draft policy documents), these were usually outside of the 
scope of i-labs. The 'political blind spot' might indeed be a format of a survival strategy as well. When things become under high-level political scrutiny or there is conflict between ministries - "it is altogether a different ball game" -, i-labs tend to disengage from the projects or deem them as possible failures. The interviewed executives partially acknowledged that political patronage is sometimes accompanied by politically defined projects that are not well thought through and proposed because of the relationship between the ministry and the social partners. When the former do not succeed, there is more scrutiny towards i-lab activities and the more policy driven the activities become, the more resistance in- and outside the public sector they encounter.

\section{Role of i-labs in the public sector}

The discussion above shows that i-labs by their nature exist in turbulent and conflicting environments (be it in terms of technological change and accompanying user-led expectations or contradictory organizational cultures) and i-labs themselves have to justify their existence and are subject to change. Thus, it is not surprising that many ilabs are struggling to find a place in the policy-making infrastructure (Bason 2013). As mentioned above, the primary tasks of the organizations were service-centred (developing prototypes, helping to scale new solutions and building capacity and networks outside of the public service (see also figure 9)), especially for those innovation labs on the municipal level dealing with social innovation. Thus, the role of i-labs can differ in the extent to which they are called to experiment and redesign existing services and processes relishing the skunk works mentality or primarily empowering citizens and enterprises to bring forth change - innovation through the 
public sector - in an open innovation mentality. The last are exemplified by very lean budgets, crowdsourcing and lightweight structures.

Figure 9. Selected activities characteristic to i-labs (\%)

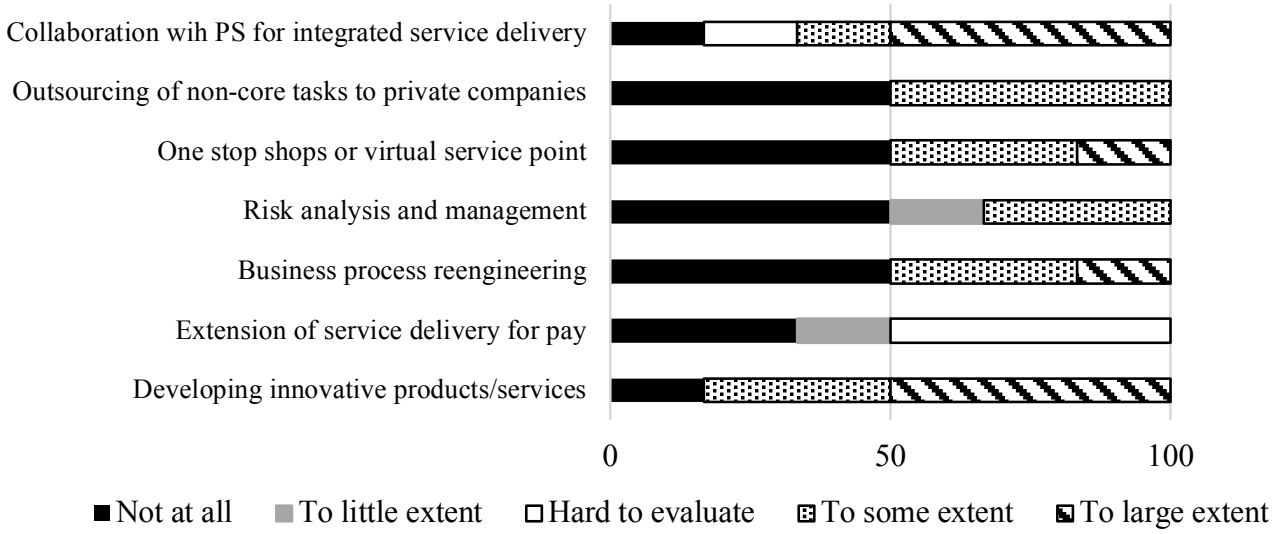

Source: Authors.

In general, i-labs consider their tasks in the public sector unique without any unit or organization similar to them in terms of tasks, output and role in the public sector. At the same time, our survey showed that they identify competition for their tasks both from inside the public sector and from private enterprises (e.g. consultancies, think thanks). However, in most cases the internalized i-lab perspective was preferred meaning that public sector i-labs should not be set up as publicly funded consultancies. The main benefits that were discussed during the interviews pertained to specific public sector experience and access to knowledge and decision makers that otherwise would be more difficult for the i-lab to attain. However, its link to the reasoning behind the creation of the i-lab was not clearly marked. Furthermore, some feared that the learning effects accompanying experimentation and development inside the public sector would not be as great if the model would be externalized. Those with prior public service experience, emphasized also public service specific motivation compared to financial motivation that in some cases had taken over and started to interfere with the goals of the i-lab as members in the lab collaborating closely with outside partners. 
While usually the goals that were mentioned during the interviews referred to complex challenges (both social and technological) that require systems change, the activities were usually directed at singular programs, projects or services. In cases where the ilab was supposed to work on higher level policy change, the organization was not successful. Only a third of i-labs in our sample engaged in implementing tasks. Thus, they primarily took up rapid prototyping and were less interested in long-term engagement, although scalability is one of the most stressed aspects in the new social innovation solutions (see Kieboom 2014). Thus, in this sense simple solutionism (rapid prototyping, quick and dirty approaches) takes hold, while complex system dynamics can be underestimated - this can hurt (social) innovation where in most cases long-term engagement is important to have a real impact (Mulgan 2009). Thus, i-labs try to capitalize on the growing trend of open data based civic apps, as more complex, political changes are outside of their control. While most i-labs did not measure the long term effects of their activities, evaluating their results and impact 3-6 months after the projects, several executives acknowledged that the prototype and accompanying change may only manifest itself after some years. Hence, in many cases there are high lead times between the project and the implementation. At the same time the question remains, how apt are i-labs in facilitating system level change (challenges from technology, external environment) or is there role in the public sector more connected to specific projects as examples and legitimizers (playing to emulation, expertise/legitimacy related goals) of further change in the other parts of public sector organization.

\section{Discussion and conclusions}


We started this article by asking why public sector innovation labs are created and how does their existence help us to explain organisational change in the public sector. I-labs, as they are created today, are rather unique in their mission, expected to act as change agents within the public sector and enjoy large autonomy in setting their targets and working methods. Thus, they definitely mirror the flexible structures characterising organisational change in many theories outlined in section two. Specifically, we found support for the role of external complexity (proposition 1), technological challenges (proposition 1.1), emulation (proposition 4) and legitimization of public sector innovation labs in the creation of i-labs (proposition 3.1). While other factors - learning (proposition 2), conflict and competition (proposition 3) - were important for the survival of such units, the empirical cases did not show that i-labs grew out of internal learning processes nor direct conflicts between old and new organisational structures.

Nevertheless, these factors were important in the functioning of public sector innovation: i-labs are typically structurally separated from the rest of the public sector and expected to be able to attract external funding as well as 'sell' their ideas and solutions to the public sector. However, depending on context their organizational build-up can considerably differ. As a rule, i-labs have no authority over other public sector structures, thus their effectiveness depends heavily on their ability to communicate and persuade other units through informal networking. This provides the i-labs the autonomy as well as incentive to experiment with new solutions and processes. Furthermore, typically i-labs have relatively low budgets and are generally small fluid organizations and are, thus, dependent on the resources (funds, human resources) they are able to co-opt to their activities externally. 
Yet, this kind of set-up also limits the ability of i-labs to catalyse and push through public-sector-wide changes. I-labs tend be small structures, specializing on quick experimentations that usually lack the capabilities and authority to significantly influence upscaling of the new solutions or processes. The main capabilities of i-labs are in their ability to jump-start or show-case user-driven service re-design projects, whereas the ability to do so often builds on antagonistic attitude of the staff who are motivated by the opportunity to prototype rather than standardize new solutions. Moreover, small size is even preferred by i-labs as it enables them to maintain agility and autonomy, as with larger budgets the hierarchical control and institutional barriers tend to increase. Interestingly, IT capabilities seem to be not that obviously present in the studied i-labs.

I-labs, although prominent in many modern public management strategies, are yet far from becoming organic part of public sector and its change. The main source of autonomy as well as survival is high level political and/or administrative support, meaning that once an i-lab loses its sponsors the survival chances diminish radically. This has created an interesting paradox - smaller i-labs are easier to close down, whereas larger i-labs face the risk of losing flexibility and freedom to act. One of the consequences of this paradox has been rather short life-spans of experimental i-labs.

Comparing the empirical results with theoretical expectations, we can argue that:

First, the initial creation of i-labs can be tied to challenges created by external complexity (user-driven innovations, economic crisis etc.) and technology (ICT) - 
propositions 1 and 1.1 - giving credence to assumptions from evolutionary and lifecycle theories and more traditional system, organisational development and contingency theories. Thus, technology plays a central role in the formation of i-labs and should be brought out separately among other complexity variables. Many of the tasks i-labs carry out are directly or indirectly related to developing ICT-based solutions for the citizens as well as the public sector. As such, i-labs do represent an attempt to make sense of increasing external complexity that is in addition to fiscal and democratic challenges related to rapid technological change.

Second, the spread of public sector innovation labs could be seen as a fad or a fashion after media success and publicity in policy circles of some of the earlier i-labs (e.g., Mindlabs) in accordance with the emulation proposition (4) coming from the newinstitutionalist theory. In other words, public sector organizations change by emulating from what is allegedly seen as international best practice. At the same time, i-labs across the world are very different - there may be some models that are isomorphic (e.g., the city innovation delivery teams in the US), usually the small units are dependent on the labbers and specific skill-sets and interests they have. Thus, we call for future studies to examine in parallel both reasons behind the creation of new organisation structures within the public sector and their survival. Specifically to the growing phenomena of ilabs, future work should analyse the different typologies of these organisations and the contextual factors that play a role in their diverging forms.

Third, one of the tasks of such semi-autonomous spaces is indeed to catalyse and legitimize change in the public sector by bringing in new kind of expertize (agency theory; proposition 3.1). By granting i-labs sufficient autonomy, providing them the 
incentive to specialize in user-driven experimentations and forcing them to develop respective capabilities, have made the i-labs useful change agents in public sector. Yet, as argued above, the risk of diminishing autonomy and lack of supportive culture and authority to routinization of new solutions limit the potential of i-labs to act the changeagent's role. It follows from the research that i-labs as they are at the moment lack sufficient resources to out-compete or challenge the existing structures. Thus, the organizational autonomy alone is insufficient to challenge existing routines in public sector. However, this is not only a one sided critique, but also the quality of work i-labs produce should be studied in detail in future research, because the "quick and dirty" methodology may also deliver incomplete or unsuitable solutions in the wider public sector context. Also, further studies should provide more evidence how exactly organizations interact with other organizations in utilizing their organizational autonomy and challenging the existing norms and routines on wider scale. Our findings indicate that instead of market competition public sector innovation assumes interorganisational collaboration and political processes (and respective capabilities) to play central role here.

Fourth, i-labs tend to be public sector units with somewhat higher mortality rate than other types of public agencies (e.g. Verhoest et al. 2012), but the direct ties to their innovation capabilities or other factors cannot be conclusively brought out in the current research. We presume that this is connected to the loss of political patronage (legitimacy) together with conflicts between new and organisational structures (connected to proposition 3 and 3.1), rather than learning or other effects (proposition 2). However, more cases beyond the three examples of 'failed' labs in our sample need to be studied for more specific conclusions. Thus, a longitudinal analysis of the survival 
of these organisations and the connected factors could expand the discussion on organisational change greatly.

Lastly, many of the i-labs tend to a large extent rely on external ICT capacities, obtained either through outsourcing or crowdsourcing. Although created to catalyse change in the public sector, i-labs themselves need to survive in the public sector context, for which relational and service design capabilities seems to be more vital than technological capabilities.

All in all, the study contributes to the understanding of organization change processes within the public sector and helps conceptualise the birth of new organisational structures. Furthermore, the study shows that the reasons for the creation of new organisational forms does not have to correspond with the reasons for survival or failure of such organisations. Thus, we call for future studies to examine in parallel both reasons behind the creation of new organisation structures within the public sector and their survival.

\section{References}

Argyris, C. (1977). Organizational learning and management information systems. Accounting, Organizations and Society, 2(2), 113-123.

Baker, W.E. (1992). The network organization in theory and practice. In N. Nohria and R. Eccles (eds.), Networks and Organization: Structure, Form, and Action. Boston, MA: Harvard Business School Press, 397-429.

Bason, C. (2013). Design-Led Innovation in Government. Available at: http://designthinkingsydney.com.au/sites/default/files/3.\%20Spring_2013_Des ign_Led_Innovation_in_Government.pdf (accessed 12.11.2014)

Bellefontaine, T. (2012) Innovation Labs: Bridging Think Tanks and Do Tanks. Policy Horizons Canada. Available at: http://www.horizons.gc.ca/eng/content/innovation-labs-bridging-think-tanksand-do-tanks (accessed 28.10.2014)

Berger, P., \& Luckmann, T. (1966). The social construction of knowledge: A treatise in the sociology of knowledge. Soho, NY: Open Road Media. 
Boulding, K.E. (1956). General systems theory-the skeleton of science. Management Science, 2(3), 197-208.

Burns, T.E., \& Stalker, G. M. (1961). The Management of Innovation. London: Tavistock.

Burstein, R. \& Black, A. (2014) A Guide for Making Innovation Offices Work. Innovation series. Washington, DC: IBM Centre for the Government.

Chesbrough, H.W. (2003) Open innovation: The new imperative for creating and profiting from technology. Cambridge, MA: Harvard Business Press.

Child, J. (1972). Organizational structure, environment and performance: The role of strategic choice. Sociology, 6(1), 1-22.

Christensen, C.M. \& Raynor, M.E. (2003) The Innovator's Solution: Creating and Sustaining Successful Growth. Boston, MA: Harvard Business School Press.

Christensen, C.M. (2006) The ongoing process of building a theory of disruption. Journal of Product innovation management, 23(1), 39-55.

Collins, R. (1974). Reassessments of sociological history: The empirical validity of the conflict tradition. Theory and Society, 1(2), 147-178.

Coriat, B. \& Weinstein, O. (2002) Organizations, firms and institutions in the generation of innovation. Research Policy, 31(2), 273-290.

Cyert, R.M., \& March, J.G. (1963). A behavioral theory of the firm. Englewood Cliffs, NJ: Prentice-Hall.

DiMaggio, P.J., \& Powell, W.W. (Eds.). (1991). The new institutionalism in organizational analysis. Chicago, IL: University of Chicago Press.

Donaldson, L. (1987). Strategy and structural adjustment to regain fit and performance: in defence of contingency theory. Journal of management studies, 24(1), 1-24.

Doorley, S., \& Witthoft, S. (2012) Make space. How to set the stage for creative collaboration. Hoboken: John Wiley \& Sons.

Eisenhardt, K. M. (1989). Agency theory: An assessment and review. Academy of Management Review, 14(1), 57-74.

Flyvbjerg, B. (2006). Five misunderstandings about case-study research. Qualitative Inquiry, 12(2), 219-245.

Freeman, C., \& Perez, C. (1988). Structural crises of adjustment, business cycles and investment behaviour. London: Pinter.

GAO (2014) Office of Personnel Management. Agency Needs to Improve Outcome Measures to Demonstrate the Value of Its Innovation Lab. Report to Congressional Requesters.

Hannan, M. T., \& Freeman, J. (1989). Organization ecology. Cambridge, MA: Harvard University Press.

James, O. \& Van Thiel, S. (2011). Structural Devolution to Agencies. In: Christensen, T. and P. Lægreid (eds.) The Ashgate Research Companion to New Public Management. Ashgate, 209-222.

John, P. (2014). Policy entrepreneurship in UK Central government: The Behavioural Insights Team and the uses of RCTs. Public Policy and Administration, 29, 3.

Kattel, R.; Cepilovs, A.; Drechsler, W.; Kalvet, T.; Lember, V. \& Tõnurist, P. (2014). Can we measure public sector innovation? A literature review. LIPSE Working papers, 2, 1 - 45 .

Katz, D., \& Kahn, R. L. (1978). Organizations and the system concept. New York: John Wiley and Sons.

Kieboom, M. (2014). Lab Matters: Challenging the practice of social innovation laboratories. Amsterdam: Kennisland. 
Kim, Y. (2010). Stimulating Entrepreneurial practices in the public sector: The roles of organisational characteristics. Administration and Society, 42, 780-814.

Langlois, R.N. (2007). Dynamics of Industrial Capitalism: Schumpeter, Chandler, and the New Economy. Londong and New York: Routledge.

Lawrence, P.R., \& Lorsch, J.W. (1967). Differentiation and integration in complex organizations. Administrative Science Quarterly, 12(1), 1-47.

Leadbeater, C. \& Miller, P. (2004) The Pro-Am Revolution: How Enthusiasts Are Changing Our Economy and Society. London: Demos.

Lewin, K. (1947). Frontiers in group dynamics II. Channels of group life; social planning and action research. Human relations, 1(2), 143-153.

Lynn, L. (2013). Innovation and Reform in Public Administration: One Subject or Two? In Osborne, S. \& Brown, L. (eds), Handbook Of Innovation In Public Services. Cheltenham: Elgar.

March, J.G. (1981). Footnotes to organizational change. Administrative Science Quarterly, 26, 563-577.

March, J.G. (1991). Exploration and Exploitation in Organizational Learning. Organization Science, 2(1), 71-87.

Margetts, H., \& Dunleavy, P. (2013). The second wave of digital-era governance: a quasi-paradigm for government on the Web. Philosophical Transactions of the Royal Society A: Mathematical, Physical and Engineering Sciences, doi:10.1098/rsta.2012.0382.

Mayo, E. (1946). The Human Problems of an Industrial Civilization. Boston, MA: Harward Business School.

Mintzberg, H. (1979). The structuring of organizations. Englewood Cliffs, NJ: Prentice Hall.

Mulgan, G. (2009). Strengths, weaknesses and a way forward? Available at: http://www.socialinnovationexchange.org/designforsi/blog?page=1 (accessed 11.05.2015)

Mulgan, G. (2014). Design in public and social innovation. NESTA website. Available at:

http://www.nesta.org.uk/sites/default/files/design_in_public_and_social_innov ation.pdf (accessed 11.05.2015)

Osborne, S.P. \& K. Brown (2013). Introduction: innovation in public services. In Osborne S.P. and Brown L. (eds) Handbook of Innovation and Change in Public Sector Services. Northampton, MA: Cheltenham, 1-14.

Pärna O. \& von Tunzelman N., (2007). Innovation in the public sector: Key features influencing the development and implementation of technologically innovative public sector services in the UK, Denmark, Finland and Estonia. Information Polity, 12, 109-125.

Parsons Desis Lab (2013). Government Innovation Lab Constellation. Available at: http://nyc.pubcollab.org/files/Gov_Innovation_Labs-Constellation_1.0.pdf (Accessed 27.06.2014)

Perez, C. (1983). Structural change and assimilation of new technologies in the economic and social systems. Futures, 15(5), 357-375.

Pollitt, C. (2004). Theoretical overview. In: Pollitt, C., \& Talbot, C. (Eds.) Unbundled government: a critical analysis of the global trend to agencies, quangos and contractualisation. London: Routledge, 319-342.

Pollitt, C. (2009). Structural change and public service performance: international lessons?. Public Money \& Management, 29(5), 285-291. 
Pollitt, C. (2010). Technological Change: a central yet neglected feature of public administration. NISPAcee Journal of Public Administration and Policy, 3(2), $31-53$.

Pollitt, C. (2011). Innovation in the public sector: an innovatory overview. In Bekkers, V., Edelenbos, J. \& Steijn, B. (eds.) Innovation in the public sector: linking capacity and leadership, 35-43. Basingstoke: Palgrave/Macmillan,.

Puttick, R. (2014). Innovation Teams and Labs. A Practice Guide. London: Nesta.

Puttick, R., Baeck, P. \& Colligan, P. (2014). i-teams: the teams and funds making innovation happen in governments around the world. London: Nesta and Bloomberg Philanthropies.

Rogers, E.M. (1995) Diffusion of innovations. New York, NY: Free Press.

Schein, E.H. (1996). Culture: The missing concept in organization studies. Administrative Science Quarterly, 41, 229-240.

Senge, P.M. (1990). The fifth discipline. New York: Doubleday.

Ståhlbröst, A. \& Holst, M., (2013) The Living Lab Methodology Handbook. Available at:

http://www.ltu.se/cms_fs/1.101555!/file/LivingLabsMethodologyBook_web.p df (accessed 14.04.2015)

Taylor, F.W. (1911) The principles of scientific management. New York: Harper and Row.

Tiesinga, H. \& Berkhout, R. (eds.) (2014) Labcraft: How innovation labs cultivate change through experimentation and collaboration. London: Labcraft Publishing.

Tõnurist, P.; Kattel, R. \& Lember, V. (2015). New Leisure Class and Conspicuous Politics in Urban Regeneration Initiatives. Working Papers in Technology Governance and Economic Dynamics, 64, 1 - 24.

Townsend, A.M. (2013) Smart cities: Big data, civic hackers, and the quest for a new utopia. New York: W.W. Norton \& Company.

Trist, E.L. (1978). On socio-technical systems. Sociotechnical systems: A sourcebook. San Diego, CA.: University Associates.

Tushman, M.L. \& O'Reilly, C.A. III (2002) Winning through Innovation: A Practical Guide to Leading Organizational Change and Renewal. Boston, MA: Harvard Business School Press.

Tushman, M.L. \& Romanelli, E. (1985). Organizational metamorphosis: A punctuated equilibrium model of organizational evolution. Research in Organizational Behavior, 7, 171-222.

UNICEF (2012) UNICEF Innovation Labs: A Do-It-Yourself Guide. Available at: http://www.unicef.org/videoaudio/PDFs/Innovation_Labs_A_Do-ItYourself_Guide.pdf (Accessed 4.05.2015)

Van de Ven, A. H., \& Poole, M. S. (1995). Explaining development and change in organizations. Academy of management review, 20(3), 510-540.

Weber, M. (2009). Wirtschaft und Gesellschaft. Grundriß der Verstehenden Soziologie, 5th ed. Tübingen: Mohr Siebeck.

Verhoest, K.; Van Thiel, S.; Bouckaert, G. \& Lægreid, P. (2012). Government agencies: practices and lessons from 30 countries. Houndmills, Basingstoke: Routledge.

Williamson, B. (2014). Knowing public services. Cross-sector intermediaries and algorithmic governance in public sector reform. Public Policy and Administration, 29(4), 292-312. 


\section{Appendices}

Appendix A.1. List of interviewed i-labs

1) C. Bason, Mindlab, Denmark, 7.10.2014

2) A. Roberts, DesignGov, Canberra, 16.10.2014 (closed down)

3) S.Vincent, La 27e Region, Paris, France, 17.10.2014.

4) E. Barrett, Silk, Kent, UK, 2.12.2014

5) C. Mauldin, Public Policy Lab, New York, US, 27.10.2014

6) J. van den Steenhoven, Director, MaRS Solutions Lab, Toronto, Canada, 30.10 .2014

7) A. Calderón Mariscal, Digital Nation Mexico, Open Mexico, Mexico, 10.11.2014

8) G. Gómez-Mont, Mexico City's Laboratorio para la Ciudad, or LabPLC, Mexico City, Mexico, 13.11.2014

9) M. Kieboom, Kennisland, Amsterdam, The Netherlands, 26.11.2014

10) M. Steinberg, Helsinki Design Lab, Sitra, Helsinki, Finland, 27.11.2014 (closed down)

D. Ni Raghallaigh, The Studio, Dublin, Ireland, 2.12.2014 (closed down) 
